\author{
ARTICLES \\ PLANNING AND PUBLIC POLICIES
}

\title{
FROM ORDINANCES TO LEGAL NORMS: THE TRAJECTORY OF PROPERTY RIGHTS IN BRAZIL
}

\author{
Gislene Pereira* \\ *Universidade Federal do Paraná, Programa de Pós-graduação em Planejamento Urbano, Curitiba, PR, Brazil
}

\begin{abstract}
This text presents the trajectory of the concept of property rights in Brazil. Identifying the Philippine Ordinances as the historical origin of the legal norms that govern property rights in Brazil, this paper recognizes the permanence and transformations of the concept over time. Through the analysis of key legal documents of a national scope, the text follows the transformation process of the concept of property, defining the moments of inflection. From within this scenario, the future of the concept is discussed, considering the conditions in which the growing urbanization in Brazil occurs. Lastly, it is questioned whether it is possible for the analyzed trajectory to incorporate use as a defining aspect of property relations.
\end{abstract}

Keywords

Property; Land Use; Urban Law. 


\title{
DAS ORDENAÇÕES AO ORDENAMENTO: A TRAJETÓRIA DO DIREITO DE PROPRIEDADE NO BRASIL
}

\author{
Gislene Pereira* \\ *Universidade Federal do Paraná, Programa de Pós-graduação em Planejamento Urbano, Curitiba, PR, Brasil
}

\begin{abstract}
Resumo
Este texto apresenta a trajetória do conceito de direito de propriedade no Brasil. Identificando as Ordenações Filipinas como a origem histórica das normas legais que regem os direitos de propriedade no país, é feito um reconhecimento das permanências e transformações do conceito ao longo do tempo. Por meio da análise dos principais documentos legais de alcance nacional, o texto acompanha o processo de transformação do conceito de propriedade, delimitando os momentos de inflexão. Com base nesse cenário, discute-se o futuro do conceito, considerando as condições em que ocorre a crescente urbanização do Brasil. Por fim, questiona-se a possibilidade de a trajetória analisada incorporar o uso como aspecto definidor das relações de propriedade.
\end{abstract}

Palavras-chave

Propriedade; Uso do Solo; Legislação Urbanística. 


\section{FROM ORDINANCES TO LEGAL NORMS: THE TRAJECTORY OF PROPERTY RIGHTS IN BRAZIL}

Gislene Pereira

Introductory notes: the trajectory of a concept

The starting point for this work is taken from the words of Rodotà (1990, apud COSTALDELLO, 2006, p. 15): “[...] from time to time, there is a revival of the proprietary issue [...] the enigma of property remains intact before us [...] and restores the former greatness". ${ }^{1}$

Coutinho, Prol and Miola (2018) reinforced this statement, revealing that "property embodies a set of legalized social relations, i.e., formalized and mediated by legal norms and institutions". Under these conditions, the forms that rights take on regarding property " $[$...] reflect past choices, making distributive arrangements permanent, defining and legitimizing who wins and who loses through legal institutions that regulate how acquisition, transfer and the loss and possession of property occur" (COUTINHO; PROL; MIOLA, 2018, p. 13).

It is from this recognition of the relationship between property and society that Rabello (2016) indicated the need to understand the historical trajectory of the concept of property. Essentially, as the author states, the regulation of property use in the nineteenth and twentieth centuries could not be the same as that of urban society in the twentieth-first century. If society has been transformed, so property has also had to be transformed. In other words, the concept and content of property rights are continually being adapted, in line with the changes that society is experiencing.

1. This and all non-English citations hereafter have been translated by the author. 
Within this context, this paper sets out to present the trajectory of the concept of property rights in Brazil, identifying the different forms that the legal organization of the relationship between people and land has taken on. Based on this identification, possible pathways of property relations are conjectured, recovering, for this, the concept of use and of the common, by Dardot and Laval (2017).

\section{In the beginning it was use: the fundamentals of property}

Here property is considered as a social construction that has always been present throughout human history, even if with different foundations and in relation to different objects. It should be mentioned, however, that while "property" and "property rights" are distinct items, they are nevertheless associated. Although it is possible to state that property has always existed, it has not always been individualized. According to Ferri (2014), it was the concept of the right to property that introduced the sense of the sole proprietor, although this only concerned the right to use things or their products.

For Assis (2008, p. 782), the appropriation of land, either individually or collectively, developed almost "jointly with the transition from the phase of the hunting man to that of the sedentary man, when civilization becomes based on certain physical spaces, with the removal of their livelihood and values away from the land". However, according to Assis (2008, p. 785), the "positivization of property as an absolute right finds support in the liberal movements that culminated in the creation of the French, 1789 [,] and North American, 1787, constitutions”. Based on these two legal documents, property became a positive ${ }^{2}$, absolute, imprescriptible, and inalienable right. However, with the Industrial Revolution, at the end of the eighteenth century, the absolutism of this right began to be contested. In the 1919 Weimar Constitution, property was no longer seen only as a right; obligations were also associated with it: "Property obliges. Its use must, at the same time, serve social well-being” (ASSIS, 2008, p. 785).

When analyzing the situation of Brazil within this context, it seems that the issue of land appropriation appeared from the time of the hereditary captaincies. Established by King John III of Portugal, from 1532, the captaincy regime aimed to encourage settlement across the territory. Regulated by the Manueline Ordinances

\footnotetext{
2. Natural rights correspond to those acquired at birth, resulting from a set of principles and values, and are immutable and valid in every place. Positive rights correspond to the norms defined by man, and are, therefore, valid only in certain places and liable to changes. LAMOUNIER, M. A. Natural rights and positive rights and their historical context: Lições de Norberto Bobbio. Âmbito Jurídico Journal, $\mathrm{N}^{\circ}{ }_{163}$, year XX, Aug. 2017. Available at: https://ambitojuridico.com.br/edicoes/revista-163/o-direito-natural-e-o-direito-positivo-e-seu-contexto-historico-licoes-de-norberto-bobbio/. Viewed on: May 18, 2019.
} 
and, later, by the Philippine Ordinances, the institute divided the territory into portions (captaincies), which were donated to private individuals (donatários lord proprietors); these were granted the power to distribute lands. This form of land distribution was called sesmaria ${ }^{3}$ It should be clarified that the Philippine Ordinances correspond to a compilation of laws ordered by Philip I, King of Spain and Portugal, and arrived in Brazil with King John VI and the Royal Family, and governed the legal norms in civil matters until 1916, when the Civil Code was approved (ALMEIDA, 1985).

Nozoe (2006) stated that sesmarias constituted the basic legal regime of the land in Colonial Brazil, and drew attention to the fact that the regime of sesmarias was brought to Brazil as a direct transfer of Portuguese legislation, designed to deal with peculiarities of the lands belonging to the kingdom of Portugal. The simple transfer of the norms, without considering the characteristics of the Brazilian territory, extensive and unoccupied, ultimately defined an occupancy regime that was extremely confusing and difficult to control.

Initially, sesmarias were granted only to Portuguese citizens; only in 1808 was the concession granted to foreigners. The only requirements imposed upon the sesmeiro were the payment of a tithe to the Order of Christ and the cultivation of the land, within a defined period, which could vary from between two to five years. If cultivation was not proven, the concession was withdrawn, and the land returned to the public domain. The Military Order of Christ was instituted by King Denis in 1318 and confirmed by Pope John XXII in 1319. It was a religious order, with the pope as sovereign, although the Portuguese Crown wielded total control over it. It inherited the assets of the Order of the Templars, and the funds raised were used for the voyages of discovery.

According to Varela (2005, p. 73), the assumption of the sesmarias in Brazil was the public character of the lands, i.e., "the fact that the territories were the vested property of the crown, under the spiritual jurisdiction of the Order of Christ”. For Varela, sesmarias in Portuguese society was just one of the dominant forms, but in Brazil, it became a general rule. Indeed, donating sesmarias was the only way to attain land in the colonial territory.

The regime of sesmarias specified the history of land appropriation ${ }^{4}$ in the country. In most colonizing countries, the individualization of property occurred

3. Translator's note: The term sesmaria originated in Portugal in 1375 and is used to indicate a plot of land of varying sizes granted by the Portuguese monarchy to petitioners (sesmeiros) in colonial Brazil in recognition of service to the crown. There is no equivalent term in English.

4. For Varela (2005, p. 86) it was “a form of appropriation, which here we term 'non-absolute property', conditioned by countless duties, and which comes close to a concession or privilege”. 
as a result of a rupture with the duties and obligations of peasants towards the feudal lord. In Brazil, however, it resulted from a rupture with public property, represented by the institution of sesmarias.

In addition, failure to comply with the exploitation requirements of the sesmaria resulted in it being rescinded, and it is this possibility of recovering land by the owner/Crown that, according to Varela (2005), defined the characteristics of land ownership at the beginning of Brazilian colonization.

As Paes (2018, p. 42) explains, during this period, and until the middle of the nineteenth century:

\begin{abstract}
Possession - and not a title deed to a property - was at the center of these relationships. The main form of recognizing a legitimate legal relationship between a person and a thing was undertaken by identifying the effective use of that thing, rather than through the existence of an individual title of a property concession agreement. [...] In other words, the Brazilian legal environment of the early decades of the nineteenth century was not guided by the centrality of the notion of individualized, titled property, but by the conviction that rights were acquired as they were exercised.
\end{abstract}

Marés (2003, p. 27) endorsed that, in the sesmarial system, the "right to land [...] was conditioned to its use; to its transformation". He added that: "[...] the first document providing evidence of the private ownership of land in Brazil is the sesmaria concession title deed" (MARÉS, 2003, p. 63). It is thus that Wehling (apud VÍCOLA, 2009, p. 92) stated that the regime of sesmarias, and therefore the concept of property associated with its use, is configured as "the key to the property regime in Brazil until the nineteenth century".

The ordinances defined a limit on the size of the sesmarias, linking the concession to an area that the recipient was able to take advantage of, within the stipulated time defined by law. However, the precariousness of the production system of colonial Brazil, aiming to meet the needs of Portugal, led to an increase in sesmaria concessions, and the mandatory relationship between size and actual use ceased to exist. This was because the structure of Brazilian agricultural production at that time was centered around the cultivation of sugar cane and sugar mills, which required large tracts of land, areas larger than those provided for in the rules of the Portuguese sesmarias.

In an attempt to regulate the expansion of the area of sesmarias, royal charters were issued, which defined the maximum extensions of the area, and requirements for the proof of use and other details of the concessions. Over time, this represented a set of laws that became difficult to understand, and, as a consequence, in the 
second half of the nineteenth century, the territorial organization of Brazil was characterized by a large number of unregulated or abandoned sesmarias due to the difficulties involved in maintaining them. Thus, the appropriation of these lands by "squatters" became common, which generated a system whereby there were no rules of land occupation, and that occurred in a manner associated with the cession agreements of sesmarias. There were, therefore, frequent judicial discussions on property delimitations, which led to the gradual reduction of concessions, until, in 1822, the sesmarias were definitively extinguished.

The extinction of the institution of sesmarias occurred at the same time that international trade was pushing for an end to the slave trade. A ban on the importation of slaves ensued and affected the Brazilian productive system, prompting the initiation of discussions on legislation that would be capable of regulating access to land for workers who were to be freed. This was the context in which Law No. 601 of 1850 (BRAZIL, 1850) was approved, which defined the conditions for land appropriation in Brazil.

Varela reported that the Land Law ended a "long chapter of Brazil's territorial history”, by eliminating possession as the predominant mode of access to land and thereby breaking the "principle of cultivation, which had had such a long history in law". For Varela, this laid the foundations for "a new conformation of the proprietary model” in Brazil (VARELA, 2005, p. 118).

\section{The plenitude of property law}

According to Varela (2005), the approval of the Land Law complied with two aspects: it enabled a transition from slave labor to free labor, a consequence of suspending the slave trade, and, at the same time, it permitted the imperial state to have control over the vacant lands, which, since the extinction of the sesmarias, had become private patrimony. According to the Land Law (BRASIL, 1850), vacant lands were those "that had no national, provincial or municipal public use; were not in the private domain; and had not granted by sesmarias nor occupied by possession".

To effect this transition period, the Law of 1850 sought to legitimize the existing possessions, maintaining the criterion of effective cultivation, according to its Article 4:

The sesmarias, or other concessions by the General or Provincial Government, that are found to be cultivated, or with the principles of culture, and deemed as the regular address of the respective sesmeiro or concessionaire, or of their representative body, even though none of the other conditions with which they were granted have been met. (BRASIL, 1850) 
At the same time, the law prohibited the possession of vacant land and instituted purchase as the only form of access, as stated in its Article 1: "The acquisition of vacant land is prohibited under a title other than that of purchase" (BRAZIL, 1850).

According to Fonseca (2005), the purpose of the new law was to end traditional forms of access to land (sesmarias and possession), and to regularize existing possessions up until that moment, provided that specific conditions related to use were met, and, above all, to clearly differentiate between private properties and the public domain. For Fonseca, "from then on, finally, it was possible to observe the figure of the owner emerging, whether it was a private owner or the State owner" (FONSECA, 2005, p. 110).

The Land Law, therefore, provided legal status to individual property in Brazil, and established the title deed for this; use ceased to be the foundation of property and a separation was made between the public and private domains. When formalizing the title deed of a property as a basic document for certification, the law modified the concept of ownership: proof of use as a property criterion was replaced by proof of title, as explained by Paes (2018, p. 43):

In Brazil, possession prevailed as the structuring category of relations between people and things throughout much of the nineteenth century, making it possible to identify the beginning of a process whereby the title was the predominant form of acquiring and proving rights over things, approximately, around the 1870 .

Land, until then publicly owned - by the Crown -, became individualized and commercialized according to the purchasing power of the interested party. The law provided for the possibility of regularizing possession, using procedures that culminated in providing a deed of a title, symbolizing, according to Bürger and Capelotti (2017, p. 29), "the path of the informality of facts (simple possession) towards the kingdom of the formality of law, of property". Considered as something individual, property now needed a title in order to be proven.

The conception of property as a total and individual right was defended in the Constitution of 1824 and, subsequently, by the Republican Constitution of 1891 . In both cases, the content of the relevant article is practically the same, making it clear that, in the case of public utility, compensation should be paid to the owner.

The 1891 Constitution makes reference to the right to property in the Declaration of Rights chapter, Article 72, Paragraph 17: "The right to property is maintained in all its plenitude, except expropriation for necessity, or public utility, through prior indemnity" (BRAZIL, 1891; emphasis added). 
The 1824 Constitution (BRASIL, 1824) also defined, in Item XVII of Article 179, that a Civil Code should be drawn up, which was approved only in 1916. And, according to Assis (2008), although it was innovative in addressing the legal relationship of the right to property, it only ratified the previous concepts.

In Article 524, the Civil Code of 1916 provided: “The law guarantees the owner the right to use, enjoy and dispose of his assets, and to recover them from within the power of anyone who unjustly possesses them”. And Article 527 was a complement, by defining that "the domain is presumed exclusive and unlimited, until proven otherwise” (BRASIL, 1916).

For Soares (2018), although the 1916 Code established certain limitations for property, when considering the right of neighborhood, it did not take into account the limitations related to collective rights, since it maintained the individualist conception of property, which until then had been predominant.

\section{Some changes: property and social well-being}

It was only in the 1934 Constitution (BRAZIL, 1934) that legislative norms indicated that the right to property could not be exercised against social or collective interest.

This concept was reproduced in the 1937 Constitution (BRAZIL, 1937), granted in the context of establishing the Estado Novo or Vargas Era, a regime established in Brazil after the Getúlio Vargas coup, between 1937 and 1946. In its Article 122, the law reinforced that the right of property may not be opposed to social interest, and also established the possibility of expropriation, to be regulated by complementary laws.

After President Getúlio Vargas was deposed in 1945, the redemocratization of Brazil began, culminating in the 1946 Constitution, in which Article 141, Paragraph 16, established that "the right to property is guaranteed, except in the case of expropriation due to necessity or public utility, or for social interest, upon prior and just compensation in cash" (BRASIL, 1946).

Despite the individualization of property that this paragraph makes explicit, Article 147 of the 1946 Constitution links the concept of property to social wellbeing: "The use of property will be conditioned to social well-being. The law may, in compliance with the provisions of Art. 141, § 16, promote the fair distribution of property, with equal opportunity for all” (BRASIL, 1946; emphasis added).

It was in the 1967 Constitution that the term "social function of property" first appeared, as a principle of economic and social order. However, the link between urban property and social function was only consolidated in the text of the 1988 Federal Constitution (BRASIL, 1988), discussed below. 
3.1. The social function of property as a legitimate principle for defining urban land use

The 1988 Constitution, in Item XXII of Article 5, confirms the right to own property as a fundamental right, and establishes, in Item XXIII, that property must fulfill its social function (BRASIL, 1988). According to Fernandes and Alfonsin (2016), in addition to traditional administrative limitations, this conception confirms the State's power to establish certain obligations for the owner (with obligations of to do, not to do, to bear, to install or to build).

For Silva (2010), the inclusion of the principle of social function, contained in Article 182 of the 1988 Federal Constitution, modified the nature of the right to property, which could no longer be seen as an individual right. Silva (2010, p. 72) highlighted that:

The social function is manifested in the very structural configuration of the right to property, placing itself firmly as a qualifying element in predetermining the modes of acquisition, enjoyment and use of goods. [...] The insertion of the principle of social function, without impeding the existence of the institution, changes its nature.

Therefore, the concept of property linked to the social function it plays determines that, in addition to rights over land, duties are linked to the title of the property with regard to meeting collective interests.

Along the same lines, Comparato (1986) stated that the adjective "social", associated with the word "function", indicated that the constitutional charter had linked property to collective interest. In the author's words, "this social function of property corresponds to a power-duty of the owner, sanctioned by the legal order" (COMPARATO, 1986, p. 76).

Grau (1983, p. 65) confirmed this position, stating that "property cannot be used in a way that is contrary to social utility, preserving the right of the owner as long as its use was not contrary to social interest”. For Cardoso (2008, p. 103), the social function could be situated, in accordance with the 1988 Federal Constitution, as an "intrinsic element to property".

Created after the 1988 Constitution, the Civil Code, approved in 2002 (BRAZIL, 2002) and in force until today, explains in Article 1,225, the concept of the right of property as a real right, which signifies considering it with a view to the legal relations of man with the objects he owns, in contrast, therefore, to personal law, which deals with the relations between subjects. 
By associating the right to property with the fulfillment of economic and social purposes (Article 1,228) and defining the non-fulfillment of that purpose as an unlawful act (Article 187), the Civil Code defends public interest, making individual interests subject to it. The 1988 Constitution and the 2002 Civil Code, therefore, established limits and criteria for property rights, the observance of which is a condition for ensuring the maintenance of property.

The Civil Code determined, in Cardoso's opinion (2008), that the property needed to be comprehended from the viewpoint of the social function of the good. Thus, it may be inferred, in relation to urban land, that the power of the owner's choice as to the use to be given to the land would be limited by the need to meet social interests. The fulfillment of these interests would also affect fruition, i.e., "in the production and destination of the fruits arising from the use given to the property by its owner". The same happens with the disposition, since urban legislation establishes minimum dimensions and occupation parameters for urban properties. Thus, for Cardoso, the legal norms began to restrict the totalitarian and individualistic character of urban property.

Articles 182 and 183 of the 1988 Federal Constitution, which make up Chapter II, on Urban Policy, were regulated by Federal Law No. 10,257/01, and termed the City Statute. In the single paragraph of Article 1, it reads: "For all purposes, this Law, termed the City Statute, establishes rules of public order and social interest that regulate the use of urban property for the benefit of the collective, and for the security and well-being of citizens, as well as environmental balance" (BRASIL, 2001).

Rabello (2016) claimed that the City Statute is the most important law on urban rights in Brazil, due to materializing the national principles and guidelines of urban policy established by the 1988 Constitution. She explained (2016, p. 485) that the norms, which regulate property rights, until the advent of the City Statute, were regulated by the Civil Code and "the effect of municipal urban norms was therefore neglected in modulating the content of urban property rights, especially with regard to the use of that property".

The 1988 Federal Constitution and the Statute therefore modified the scale that needs to be considered in order to comply with the principle of the city's social function. This function is no longer considered lot by lot, since "the regulation unit is the city as a whole" (RABELLO, 2001, p. 487). According to Rabello, the legislation has evolved in the understanding that urban regulation goes beyond the simple administrative limitation of the use of property. In other words, urban laws do not impose limitations on the right to property; instead, they regulate the use of the city to enforce the social function of property. 


\section{The right to property in Brazil: a spiral in time}

Taking Paes (2018, p. 42) as a reference, for whom "property, possession and title are legal institutions in constant transformation", the table below presents a chronological synthesis of how the concept of property in Brazil has been conformed, aiming to demonstrate that this concept is not immutable, that it follows the dynamics of society.

As discussed throughout the text, until the beginning of the nineteenth century, use was what defined property and the right to it. This concept continued to change, and the Law of 1850 confirmed the predominance of purchase as being the access to land. From then on, the concept of property and its rights were maintained, as something that could be acquired through purchase, with use no longer standing as a foundation. From the twentieth century to the present day, one important aspect of the discussions on property rights has emphasized its social function, in an attempt to incorporate it into the urban reality prevalent in Brazil, where empty land coexists with a growing number of people who have nowhere to live.

The timeline presented in Table 1 reiterates Rabello's idea (2016, p. 483), which discusses the mutability of the concept of property rights:

This is what is happening with the so-called right to urban real estate property: an adaptation to the new reality into which it is inserted: the city. The traditional interpretation of the meaning of its content, which was plausible for the cities that we had until the middle of the twentieth century, no longer fits the phenomenon and urban society of the twenty-first century. Only conceptual evolution, through a conceptual reinterpretation, will save it; this is what is happening in Brazil, and in other parts of the world.

In other words, the concept of property rights is continuously being (re) constructed. This signifies that, according to Coutinho, Prol and Miola (2018), understanding the transformations that have occurred in the concept of property is a way of understanding the society that defines it. 


\begin{tabular}{|c|c|c|c|c|c|}
\hline \multicolumn{2}{|c|}{ Period } & Norms & Content & $\begin{array}{l}\text { Situation of } \\
\text { the land }\end{array}$ & Proof \\
\hline \multicolumn{2}{|c|}{$\begin{array}{l}\text { Sixteenth to the } \\
\text { eighteenth centuries }\end{array}$} & $\begin{array}{l}\text { Phillipine } \\
\text { Ordinances }\end{array}$ & $\begin{array}{c}\text { Sesmarias as a form of access to } \\
\text { land }\end{array}$ & Crown & \multirow{4}{*}{$\begin{array}{c}\text { use/ } \\
\text { possession }\end{array}$} \\
\hline \multirow{6}{*}{$\begin{array}{c}\text { Nineteenth } \\
\text { century }\end{array}$} & \multirow[t]{2}{*}{1822} & $\begin{array}{l}\text { Imperial } \\
\text { Resolutions }\end{array}$ & Extinction of the sesmarias & \multirow{3}{*}{ Imperial } & \\
\hline & & Royal Charters & \multirow[b]{2}{*}{ Delimitation of the old sesmarias } & & \\
\hline & 1824 & $\begin{array}{l}\text { Imperial } \\
\text { Constitution }\end{array}$ & & & \\
\hline & \multirow{2}{*}{1850} & \multirow{2}{*}{ Land Laws } & \begin{tabular}{|c|} 
Legitimizing the existing \\
possessions, maintaining effective \\
cultivation as a criterion
\end{tabular} & \multirow{2}{*}{$\begin{array}{l}\text { Imperial lands } \\
\text { put up for sale }\end{array}$} & \multirow{10}{*}{$\begin{array}{l}\text { Tilte deed of } \\
\text { ownerhsip }\end{array}$} \\
\hline & & & $\begin{array}{l}\text { Purchase as a form of } \\
\text { access to land }\end{array}$ & & \\
\hline & 1891 & $\begin{array}{l}\text { Constitution of } \\
\text { the Republic }\end{array}$ & Full ownership & \multirow{8}{*}{ Private } & \\
\hline \multirow{6}{*}{$\begin{array}{l}\text { Twentieth } \\
\text { Century }\end{array}$} & 1916 & Civil Code & $\begin{array}{c}\text { Property, respecting the right of } \\
\text { neighborhood }\end{array}$ & & \\
\hline & 1934 & Constitution & $\begin{array}{c}\text { Inclusion of collective interest as a } \\
\text { limit to owning property }\end{array}$ & & \\
\hline & 1937 & $\begin{array}{l}\text { Constitution of } \\
\text { the Estado Novo }\end{array}$ & $\begin{array}{l}\text { Possibility of expropriation for } \\
\text { purposes of public utility }\end{array}$ & & \\
\hline & 1946 & $\begin{array}{c}\text { Constitution of } \\
\text { the post-Estado } \\
\text { Novo }\end{array}$ & $\begin{array}{l}\text { Social well-being as a limit to } \\
\text { owning property }\end{array}$ & & \\
\hline & 1967 & $\begin{array}{l}\text { Constitution } \\
\text { of the military } \\
\text { period }\end{array}$ & Social function of property & & \\
\hline & 1988 & $\begin{array}{l}\text { Citizen's } \\
\text { Constitution }\end{array}$ & Property as a social function & & \\
\hline $\begin{array}{c}\text { Twenty-first } \\
\text { Century }\end{array}$ & 2001 & City Statute & Operationalizing the social function & & \\
\hline
\end{tabular}

Table 1. The trajectory of how the content of land ownership in Brazil has been conformed Source: Produced by the author, 2020.

\section{Property and the common: concepts undergoing transformation}

The presentation of the trajectory of the concept of property rights in Brazil confirms Rodota's (1990) initial statement that "from time to time, the proprietary issue is revived". Indeed, it is possible to complement it with the notion that the proprietary issue is always present and that its relevance is even greater in contemporary times, when property assumes a fundamental role in the structuring of cities.

However, Canestraro (2005, p. 17) explained that "land ownership is not just between an individual (the owner) and a thing (the land), but is a social relationship, between subjects [...]. Far from being a static entity, its definition is 
the result of a historical process that is being defined according to the conflicts for the appropriation and the occupation of the land".

And it is precisely because it is a social relationship that property has transformed over time, as observed in Table 1. Azuela (1989), in turn, affirmed that the character of the social relation of property has a direct link with the prevailing situation in almost all Brazilian cities: the growth of occupations outside the established legality. This is because the current, individualistic right to property is based on the fact that some (owners) have the ability to exclude others (nonowners) from using, enjoying and disposing of something - in this case, urban land.

In this context, the occupation of the peripheries of Brazilian cities could be analyzed according to the process through which property relations are constituted and transformed. For Azuela (1989), considering urban settlements as irregular or illegal signifies ignoring the property relations that exist within them. Indeed, the type of property relation prevailing there does not fit into the concept of property contained within legal texts in Brazil. However, property relations exist. Families build their houses on land and even sell these houses. Using the words of Canestraro (2005), the property relation found there is "the result of a historical process that is defined in terms of conflicts over appropriation and occupation" (CANESTRARO, 2005, p.16).

Fernandes and Alfonsin (2016) reiterate this position, stating that, in most Brazilian cities, a large portion of the population solves the housing problem by using processes that, to some extent, disobey the normative concept in force regarding property. These authors consider that urban "illegality" ceased to be an exception and became the rule, structuring the production process of the city. As a result, a question is generated regarding the nature of the current legal order, which emphasizes the individual view of property rights and defines what is legal and what is not.

Therefore, it is worth bringing the position of Azuela (1989) to this discussion, for whom Rights, in themselves, are nothing more than a type of discourse, which only gains meaning and consistency if they become effective in social practice. However, Azuela (1989, p. 24) highlighted that:

This does not mean that norms create social relationships, but that they give them a particular condition that anyone may recognize when they distinguish, in common language, between a situation of "fact" and one that is "official". The law provides actors with a repertoire that allows them to give a shared meaning to the relationships in which they participate, including, of course, property relations. 
In view of these assumptions, and to reflect on the possibilities of continuity in the timeline of the concept of property, the discussion put forward by Dardot and Laval (2017, p. 199) is fundamental. They indicated a transformation, already on-going, of the social relations that characterize the right to property. To explain this transformation, they use the concept of "common", translated as a term that "designates a regime of practices, struggles, institutions and research all dedicated to realizing a non-capitalist future" (DARDOT; LAVAL, 2017, p. 22). ${ }^{5}$ They claim that

[...] the principle of the common emerges out of various democratic struggles and social movements at the beginning of the twenty-first century. Its emergence signals a new era of emancipation. A new theoretical discourse is in the process of being formed, one that is closely connected to a range of alter-globalization movements and informed by multiple theoretical sources (DARDOT; LAVAL, 2017, p. 48).

To discuss the relationship between the common and private property, Dardot and Laval discussed the possibilities of the emergence of a new law, one that represents social conflicts and that strengthens the common as a political principle. In order to contribute to the advancement of this principle, the authors present proposals that relate to the discussion conducted in this work: i) make the common the fundamental principle of social transformation; ii) weigh the new right of use against the right of property; iii) create a more common world.

The second item, using the foundation provided by the abovementioned authors, leads us to discuss the sequence of the property timeline. Dardot and Laval (2017) recovered one of the aspects mentioned at the beginning of this text: the fact that the right to property in Brazil came about as a result of the right to use. In the old sesmarias, in order to be considered the owner of a piece of land, it was necessary to demonstrate the use that was intended for it. Dardot and Laval (2017, p. 477) did not propose, however, a return to old concepts of ownership. Quite the contrary in fact, the focus of the discussion would be to overcome these and then create "new use rights that impose limits on private property and even begin to rescind the institution of private property itself through the recognition of unappropriability as a hegemonic social norm".

The legitimization of these "new use rights" would be accomplished through collective practice. The authors continue that: "For while it is true that one does not decree a custom, one can nevertheless decide to establish rules that may one day

5. N.B. - For this and all other direct citations hereafter by these authors, the English version was used of DARDOT, P.; LAVAL, C. Common - On Revolution in the $21^{\text {st }}$ Century, Translated by Mathew MacLellan, Bloomsbury Academic, London. 2019. 
become custom through the sheer force of practical repetition" (DARDOT; LAVAL, 2017, p. 278). In other words, it is a matter of producing rules of law (and here the right to property is included) through a collective practice that becomes customary in the long term and then, common.

Returning to the question of Brazilian cities, it may be stated that it is possible to envision a sequence for the timeline of urban property, with the emergence of means that facilitate the institution of rules that become customs. Dardot and Laval call this process "instituent praxis":

[...] is not a matter of post facto recognition of that which already exists, nor an act of creation ex nihilo, but a form of practice that creates the new through that which already exists [...]. In order to have any chance of success, the law of the common must proceed from this type of praxis rather than solely relying on the spontaneous diffusion and transmission of customary rights. (DARDOT; LAVAL, 2017, p. 244).

The position of Dardot and Laval coincides with that of Azuela (1989, p. 229), when he states that the "norm, once produced by practice [...] i.e., once in force, is a reference for future practices and, under normal conditions, is a real conditioning factor for these practices".

What, then, could be the rules for a "new property right" that would allow the instituent practice? This is the discussion proposed by this text, when recovering the trajectory of property rights. For it is precisely because this trajectory is continuous, but not necessarily linear, that it may be stated that there are still no answers to the question presented. It is, in effect, a research agenda under construction.

However, despite this context of conceptual uncertainties, the present study indicates some paths that necessarily pass through new rules for building the city capable of incorporating the issue of use as a condition for (re)defining property rights - or, following Dardot and Laval (2017, p. 429), new rules that recognize social property relations that, incorporating the concept of common, "impose limits on private property and even begin to rescind the institution of private property itself [...].”

A further question is: what rules are capable of imposing limits on private property? The answer, brought by the trajectory presented, enables us to identify that the concept of property is governed by legal statutes that define the relationship between people and things, according to the social reality of each historical period.

Currently, in which urban reality predominates, it is, therefore, dealing with the set of rules that regulate life in the city. These same rules, in the past, were inserted into the Philippine Ordinances and, in the present, they are expressed in the municipal legislation for the control of urban land use. Thus, Rabello (2016, p. 488) states that: 
To place legal norms onto the territory is to regulate the use of this public object - the territory. But it is within it, across the territory, in this same space, where the private right to property also materializes. Territory, public object, and urban lot, object of private property, all take place within the same space, on the same soil, and the existence of one does not eliminate the existence of the other [...]. Consequently, each lot will accommodate its private uses to the public interests explained in the territorial regulation, whose unavoidable constitutional objective is to reach and provide its inhabitants with quality of life and access to the social functions of the city.

The territorial regulation of land use, therefore, translates, in urban daily life, the concept of property rights, which is dynamic and accompanies social transformations.

It may be concluded, therefore, that the rules to which Dardot and Laval refer, capable of imposing limits onto private property, are urbanistic and should reflect daily practices of land appropriation. In contemporary Brazilian cities, such practices correspond to the use of land to supply the need for housing, the use of urban land as a condition of survival.

In this sense, the concept of property rights and urban norms require a linked conception, which considers both private interests and the identification of collective needs. This signifies that the continuity of the trajectory of the concept of property would indicate the possibility of a concept based on the use and the recognition of these everyday demands. However, to continue the discussion on what would come along on the continuous timeline, it is necessary to discuss the future of contemporary society. For this, Piketty (2019, s.p.) makes an important contribution: there are always several possible ways of organizing a society and the power and property relations within it. In particular, there are many ways to organize property relations in the twenty-first century, and some may constitute much more of a real leap from capitalism than the path that consists of promising its destruction without concern about what will follow.

For this author, the choices between possible paths (for example, regarding the concept of property rights) depend on what each society understands and accepts as justice and also on the power relations between social groups. According to Piketty (2019, s.p.), these power relations are, above all, intellectual and ideological: "In other words, ideas and ideologies count in history. They permanently allow you to imagine and structure new worlds and different societies. Multiple trajectories are always possible". ${ }^{6}$

6. N.B. - For direct citations, the English version was used of PIKETTY, T. Capital and Ideology. The Belknap Press of Harvard University Press, Cambridge, Massachusetts. 2019. 
With this, the end of this paper points to the possibility of being optimistic about the contemporary city, through the construction of a positive urban utopia. Because, in fact, "no future can be seen with optimism if we do not insert a measure of utopia into this vision. Not utopia as an unrealizable dream, but as a project of actions, capable of materializing that dream” (PEREIRA, 2002, p. 3). Huyssen (2001, p. 247, 256) complements this statement:

[...] utopian thought has always survived premature burials and, at certain times, has even led to quite spectacular resurrections from the non-places on the maps of social and cultural life [...]. The current postulate that utopia has ended is no longer plausible today [...] and will fall into oblivion as soon as the next utopian sensibility resurfaces.

Every utopia has two poles: on the one hand, it criticizes the existing situation; on the other, it proposes how things should be. It would have made sense, then, to think that the property timeline could have continuity through the construction of a utopia: the common, defended by Dardot and Laval (2017) - which could constitute itself as being (and close to) "utopian sensibility".

However, it would not be a common property, but, according to the abovementioned authors (DARDOT; LAVAL, 2017, p. 504), a redefinition of the right of use:

[...] even supposing the existence and recognition of such a right, its exercise is undermined from the outset by the fact that the right of use is artificially dissociated from decisions about the rules governing resources: the right of use has no efficacy if it is cut off from the right to co-produce the rules of common use.

The trajectory of the concept of property (and utopia to be socially constructed) would thus advance towards the right to build land use in common: "Instituent use of the common is not a right of ownership: it is the practical negation of property rights in all its forms, and the only form in which the unappropriable can be properly managed" (DARDOT; LAVAL, 2017, p. 329).

With these assumptions, it would be possible to reorganize the data in Table 1 , regarding the trajectory of the concept of property rights, transforming them in Figure 1, which indicates the approaching future.

Within this context, contemplating the contemporary urban would require rethinking the building processes of the city by applying rules that facilitate the instituent praxis of the common and recovering use as a fundamental criterion, according to the co-determination of the ends or purpose of the common by those who effectively occupy the urban land (DARDOT; LAVAL, 2017). 


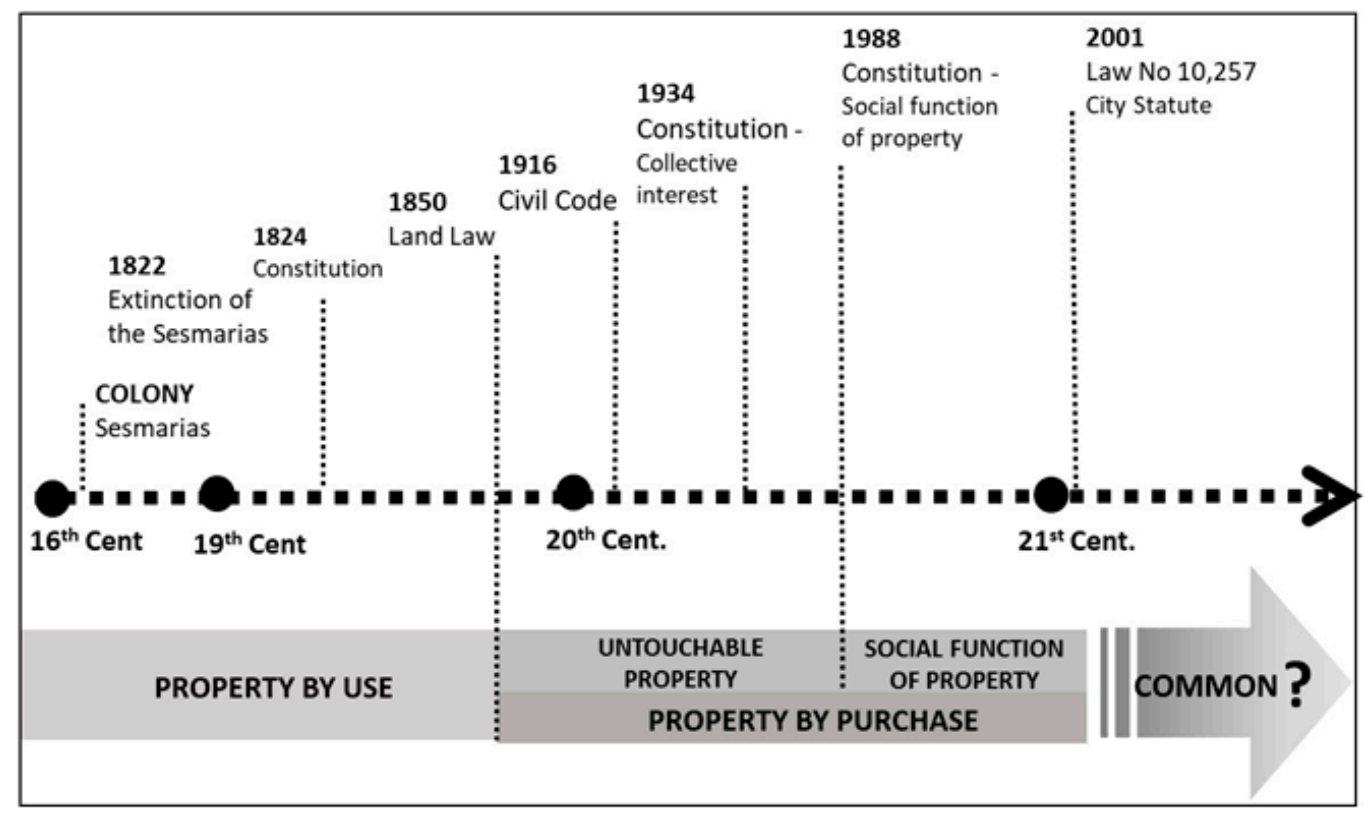

Figure 1. Synthesis of the property timeline in Brazil Source: Produced by the author, 2020.

That would be, therefore, the challenge presented by this text.

\section{Final considerations: Urban property - an incomplete trajectory}

The trajectory of the concept of property, which this text has presented, took as its starting point the assumption that there exists a legal body, which expresses the rules of the society that defines it. As Rabello (2001, p. 111) stated: "If constructing the legal system of urbanism needs to guarantee, on the one hand, the security of legal relations, on the other, it must also seek to meet, through the appropriateness of the norm, the multiple changing phatic situations, that present themselves in urban life".

The phatic situation to which the author refers is the predominant urban reality in most major cities in Brazil: land occupation without a legally valid title deed, but validated by use.

Thus, this text concludes by formulating an invitation: to format a research agenda that considers the (re)construction of rules for the use and occupation of urban land that enables the instituent praxis; of norms that contain use as a condition for the right of property, or, in accordance with what has been discussed herein, that recognize property relations, adept at incorporating the concept of common, as being legitimate.

This invitation is justified through a quote by Chauí (2000, p. 466): "The possible is not the probable. This is the predictable, i.e., something that we may calculate and foresee, because it is a probability contained within the facts and 
data that we analyze. The possible, however, is that created by our own action. It is what comes into existence thanks to our action".

Finally, it should be highlighted that this work did not cover all the problems and issues that exist concerning the discussion on property relations. Only the key moments and the essential aspects of the process of shaping property have been recognized as a right, so that, based on this, it is possible to identify new directions for the trajectory of this concept.

\section{References}

ALMEIDA, C. M. Ordenações Filipinas. Lisboa: Fundação Calouste Gulbenkian, 1985.

ASSIS, L. G. B. A evolução do direito de propriedade ao longo dos textos constitucionais. Revista da Faculdade de Direito da Universidade de São Paulo, v. 103, p. 781-791 jan.-dez. 2008.

AZUELA, A. La ciudad, la propiedad privada y el derecho. Mexico, DF: El Colegio de Mexico, 1989.

BRASIL. Presidência da República. Casa Civil. Subchefia para Assuntos Jurídicos. Constituição Política do Império do Brasil. Manda observar a Constituição Politica do Imperio, offerecida e jurada por Sua Magestade o Imperador. Coleção de Leis do Império do Brasil, 1824. Available at: http://www.planalto.gov.br/ccivil_03/constituicao/constituica024. htm. Viewed in: January 2019.

Presidência da República. Casa Civil. Subchefia para Assuntos Jurídicos. Lei $\mathrm{n}^{\circ}$ 601, de 18 de setembro de 1850. Dispõe sobre as terras devolutas do Império. CLBR de 1850. Available at: http://www.planalto.gov.br/ccivil_03/leis/lo601-1850.htm. Viewed in: January 2019.

Presidência da República. Casa Civil. Subchefia para Assuntos Jurídicos. Constituição da República dos Estados Unidos do Brasil. 1891. Diário Oficial da União, 24 fev. 1891. Available at: http://www.planalto.gov.br/ccivil_03/Constituicao/Constituicaog1.htm. Viewed in: January 2019.

Presidência da República. Casa Civil. Subchefia para Assuntos Jurídicos. Lei ${ }^{\circ}$ 3.071, de $1^{\circ}$ de janeiro de 1916. Código Civil Nacional. Diário Oficial da União, 5 jan. 1916. Available at: http://www.planalto.gov.br/ccivil_03/leis/L3071.htm. Viewed in: January 2019 .

Presidência da República. Casa Civil. Subchefia para Assuntos Jurídicos. Constituição da República dos Estados Unidos do Brasil. 1934. Diário Oficial da União, 16 jul. 1934. Available at: http://www.planalto.gov.br/ccivil_03/constituicao/constituica034.htm. Viewed in: November 2018.

Presidência da República. Casa Civil. Subchefia para Assuntos Jurídicos. Constituição da República dos Estados Unidos do Brasil. 1937. Diário Oficial da União, 10 nov. 1937. Available at: http://www.planalto.gov.br/ccivil_03/Constituicao/Constituica037.htm. Viewed in: January 2019. 
BRASIL. Presidência da República. Casa Civil. Subchefia para Assuntos Jurídicos. Constituição da República dos Estados Unidos do Brasil. 1946. Diário Oficial da União, 19 set. 1946. Available at: http://www.planalto.gov.br/ccivil_03/constituicao/constituica046.htm. Acesso em: dez. 2018.

Presidência da República. Casa Civil. Subchefia para Assuntos Jurídicos. Constituição da República Federativa do Brasil. 1988. Available at: http://www.planalto.gov.br/ ccivil_03/constituicao/constituicao.htm. Viewed in: January 2019.

Presidência da República. Casa Civil. Subchefia para Assuntos Jurídicos. Lei $n^{\circ}$ 10.257/2001 - Estatuto da Cidade. Regulamenta os arts. 182 e 183 da Constituição Federal, estabelece diretrizes gerais da política urbana e dá outras providências. Diário Oficial da União, Brasília, DF, 11 jul. 2001. Available at: http://www.planalto.gov.br/ ccivil_03/leis/leis_2001/l10257.htm. Viewed in: January 2019.

Presidência da República. Casa Civil. Subchefia para Assuntos Jurídicos. Código Civil Nacional. Lei $\mathrm{n}^{\circ}$ 10.406, de 10 de janeiro de 2002. Diário Oficial da União, Brasília, DF. 11 jan. 2002. Available at: http://www.planalto.gov.br/ccivil_03/leis/2002/10406.htm. Viewed in: January 2019.

BÜRGER, M. L. F; CAPELOTTI, J. P. O percurso da posse e da propriedade no Brasil: das sesmarias aos conceitos contemporâneos. In: ANIMA: Revista Eletrônica do Curso de Direito das Faculdades OPET, Curitiba, ano IX, n. 16, jan.-jun. 2017.

CANESTRARO, M. L. De "formas” y “normas” en la apropiación del espacio. Reflexiones para una sociología urbana crítica. IV JORNADAS DE SOCIOLOGÍA DE LA UNLP, 2005. La Plata, Argentina. Memoria Académica. La Plata: UNLP, 2005. Tema: Desigualdad social, movimientos sociales, política e instituciones. Available at: http://www.memoria.fahce. unlp.edu.ar/trab_eventos/ev.6593/ev.6593.pdf. Viewed on: November 15, 2018.

CARDOSO, F. L. Propriedade urbana no ordenamento brasileiro. Revista de Direito Administrativo, Rio de Janeiro, v. 247, p. 98-125, jan. 2008. Available at: http:// bibliotecadigital.fgv.br/ojs/index.php/rda/article/view/41549/40862. Viewed on: March 11, 2019.

CHAUÍ, M. Convite à Filosofia. São Paulo: Ática, 2000.

COMPARATO, F. K. Função social da propriedade dos bens de produção. Revista dos Tribunais, v. 25 , n. 63 , p. 71-79, jul.-set. 1986. Available at: https://edisciplinas.usp.br/pluginfile. php/1894637/mod_resource/content/o/05\%20COMPARATO.\%2oFuncao\%20social\%20 da\%2opropriedade\%2odos\%2obens\%20de\%2oproducao.pdf. Viewed on: October 8, 2020.

COSTALDELLO, A. C. As transformações do regime jurídico da propriedade privada: a influência no direito urbanístico. Revista da Faculdade de Direito da UFPR, Curitiba, dez. 2006. Available at: https://revistas.ufpr.br/direito/article/view/8754. Viewed on: January 2, 2019.

COUTINHO, D.; PROL, F.; MIOLA, I. (org.). Propriedades em transformação: abordagens multidisciplinares sobre a propriedade no Brasil. São Paulo, Edgard Blücher, 2018.

DARDOT, P.; LAVAL, C. Comum: ensaio sobre a revolução no século XXI. São Paulo: Boitempo, 2017. 
FERNANDES, E.; ALFONSIN, B. (org.). Apresentação. In: FERNANDES, E. et al. Construção do Direito Urbanístico na América Latina. Belo Horizonte: Gaia Cultural, 2016. [livro eletrônico].

FERRI, C. A. A função social da propriedade rural e seu alcance difuso e coletivo. 2014. Dissertação (Mestrado) - Programa de Pós-graduação em Direito, Faculdade de Direito da Universidade Metodista de Piracicaba, Piracicaba, 2014.

FONSECA, R. M. A Lei de Terras e o advento da propriedade moderna no Brasil. 2005. Available at: https://studylib.es/doc/5170914/a-lei-de-terras-e-o-advento-da-propriedade-moderna. Viewed on: February 7, 2019.

GRAU, E. R. Direito urbano: regiões metropolitanas, solo criado, zoneamento e controle ambiental. São Paulo: Ed. Revista dos Tribunais, 1983.

HUYSSEN, A. En busca del futuro perdido. Cultura y memoria en tiempos de globalización. Buenos Aires: Fondo de Cultura Económica de Argentina, 2001.

MARÉS, C. F. A função social da terra. Porto Alegre: Sergio Antonio Fabris. 2003.

NOZOE, N. Sesmarias e apossamento de terras no Brasil Colônia. Revista Economia, São Paulo, FEA-USP, set.-dez. 2006.

PAES, M. A. D. Das cadeias dominicais impossíveis: posse e título no Brasil Império. In: UNGARETTI, D. et al. (ed.). Propriedades em transformação: abordagens multidisciplinares sobre a propriedade no Brasil. São Paulo: Blucher, 2018. p. 41-58.

PEREIRA, G. Produção da cidade e degradação do ambiente: a realidade da urbanização desigual. 2002. Tese (Doutorado em Meio Ambiente e Desenvolvimento) - Universidade Federal do Paraná, Curitiba, 2002.

PIKETTY, T. Capital et idéologie. Extratos. Tradução: André Langer. Le Monde: Paris, 2019.

RABELLO, S. Regulação do território e da propriedade imobiliária urbana: evolução conceitual no Direito Brasileiro. In: FERRARI, S.; MENDONÇA, J. V. (org.). Direito em público. Rio de Janeiro: Lumen Juris, 2016.

O poder de polícia normativo, o direito urbanístico e as normas de planejamento urbano. 2001. Tese elaborada como requisito parcial para o concurso ao cargo de Professor Titular de Direito Administrativo da Faculdade de Direito da Universidade do Estado do Rio de Janeiro, Rio de Janeiro, 2001. Available at: http://www.soniarabello. com.br/wp-content/uploads/2012/o6/O-Poder-de-Pol\%C3\%ADcia-Normativo-o-DireitoUrban\%C3\%ADstico-e-as-normas-de-Planejamento-Urbano.pdf. Viewed in: March 2019.

SILVA, J. A. da. Direito urbanístico brasileiro. São Paulo: Malheiros, 2010.

SOARES, V. B. N. O direito de propriedade: caracterização na concepção de autores clássicos e contemporâneos e breves comentários acerca da função social. Available at: https:// www.diritto.it/o-direito-de-propriedade-caracterizacao-na-concepcao-de-autoresclassicos-e-contemporaneos-e-breves-comentarios-acerca-da-funcao-social/. Viewed on: November 15, 2018.

VARELA, L. B. Das sesmarias à propriedade moderna: um estudo de história do direito brasileiro. Rio de Janeiro: Renovar, 2005.

VÍCOLA, N. S. A propriedade imobiliária no Brasil: breve histórico. Revista Eletrônica FMU Direito, v. 23, n. 31, 2009. 


\section{Gislene Pereira}

Architect and urbanist at the Universidade Federal de Paraná (UFPR). She holds a master's degree in Urban and Regional Planning from the Instituto de Pesquisa e Planejamento Urbano e Regional da Universidade Federal do Rio de Janeiro (IPPUR / UFRJ), and a doctorate in Development and Environment from MADE/UFPR. She is a full professor on the Architecture and Urbanism course and on the Post-Graduate Program in Urban Planning (PPU) at UFPR. She is also a researcher on the theme of urban planning, with an emphasis on policies and instruments for financing urban development.

Email: gislenepereira42@gmail.com

ORCID: 0000-0003-0426-8314

Submitted: June 9, 2020.

Approved: December 14, 2020.

How to cite: PEREIRA, G. From Ordinances to legal norms: the trajectory of property rights in Brazil. Revista brasileira de estudos urbanos e regionais. v. 23, E202105en, 2021. DOI 10.22296/2317-1529.rbeur.202105en

Artigo licenciado sob Licença Creative Commons CC BY 4.0.

https://creativecommons.org/licenses/by/4.o/ 